\title{
И.С. СВИЩ
}

\section{E.B. HOCATOBA}

\section{ВЯИЯНИЕ ВИДА КАРБОНАТНЫХ ОТХОДОВ КРЫМСКИХ КАРЬЕРОВ НА ПРОЧНОСТЬ, ВРЕМЯ ТВЕРДЕНИЯ И СТРУКТУРООБРАЗОВАНИЕ ШЛАКОЩЕЛОЧНОГО БЕТОНА НА ОСНОВЕ ЖИДКОГО СТЕКЛА С СИЛИКАТНЫМ МОДУЛЕМ 1,5-1,7}

\author{
INFLUENCE OF TYPE OF CRIMEAN QUARRIES CARBONATE WASTE ON DURABILITY, \\ CURING TIME AND STRUCTURE FORMATION OF SLAG-LIME CONCRETE ON THE BASIS \\ OF SOLUBLE GLASS WITH SILICATE MODULE 1,5-1,7
}

\begin{abstract}
Рассматривается влияние вида карбонатных отходов на прочность, время твердения и структурообразование шлакощелочного бетона различных составов с разными условияли твердения на основе жидкого стекла с силикатным модулем 1,5-1,7 и отходов камнепиления известняков Крымских карьеров. Проблемность шилакощелочных вяжущих материалов заключается во времени твердения (сроках схватьвания) и влиянии этого параметра на прочность будущего бетонного камня. Было выявлено одно из направлений регулирования сроков схватывания шлакощелочных вяжущих путем введения перед помолом в доменный гранулированный шлак определенного количества отходов камнепиления известняков Крылских карьеров. Исследование влияния отходов камнепиления известняков на сроки схватывания, прочность и структурообразование шлакощелочного вяжущего и бетонов на их основе может показать механизм регулирования сроков схватьвания, что существенно поможет скорректировать технологические параметры изготовления изделий строительного назначения из это20 материала. Проведено исследование фазового состава с помощью дифференциильно-термического, рентгенофазового, микроструктурного анализов.
\end{abstract}

Ключевье слова: жидкое стекло, доменный гранулированный шлак, шлакощелочное вяжущее, структурообразование, известняк-ракушечник, отход камнепиления, микроструктура, образиьь цилинндрь

Ресурсосбережение в строительной отрасли определяется рациональным использованием природного кондиционного сырья, уровнем вовлечения в производство некондиционных накопдений (в отвалах и захоронениях), образующихся при добыче и первичной переработке сырья, использованием промышленных отходов [1-3]. Использование отходов промышленных производств - актуальная проблема для любого государства.

Известно, что дия производства шлакощелочных вяжущих веществ (ШШВ) применяют разнообразные виды шлаков металлургических производств и щелочесодержащих компонентов, таких как сода, содощелочной плав, жидкое стекло.
In the article the influence of carbonate waste on durability, curing time and structure formation of slag-lime concrete of different compositions with different curing conditions on the basis of soluble glass with silicate module Mc=1,5-1,7 is considered as well as Crimean quarries stone-cutting waste. Slag-lime binders are difficult in-use because of curing time and its influence on concrete brick durability. One of ways of setting time regulation lies in introduction of some stone-cutting waste in blast-furnace grained slag before grinding. The studies of stone-cutting waste influence on curing time, durability and structure formation of slag-lime binder and concretes on its basis are able to show mechanism of curing time regulation and it will work to correct technological parameters of construction items production. The phase composition is studied with help of the differential thermal, $x$-ray diffraction and microstructural analyses.

Keywords: soluble glass, blast-furnace grained slag, slaglime binder, structure formation, shell-limestone, stonecutting waste, microstructure, sample cylinders

Самыми многотоннажными отходами явдяются металлургические шлаки и топливные золошлаковые отходы энергетики. Вопросам разработки исподьзования этих отходов в производстве раздичных материалов посвящено большое количество исследований. Эффективное применение нашли металлургические шлаки в производстве вяжущих, заполнителей, бетонов, шлаковой ваты, дитых материалов, шлакоситаллов и других материалов.

Свойства шиакощелочных вяжущих веществ, а именно набор прочности, скорость гидратации, твердение композиций зависят от химико-минераиогического и фазового состава шлака, а также от природы щелочного компонента [4]. Рассматривая 
химико-минералогический состав портландцемента и шлакощелочного вяжущего вещества, в качестве аналога силикатной составляющей портландцемента C2S и C3S, содержание которой в нем превышает $70 \%$, может быть принят (с определенной степенью приближения) силикат натрия - растворимое стекио [5]. Важной зависимостью дия шиакощелочного вяжущего вещества является связь технологических (растворо-шлаковое соотношение $(\mathrm{P} / \amalg)$, сроки схватывания цемента) и механических свойств (предел прочности при сжатии и изгибе). На данный момент существует широкая база экспериментальных данных о свойствах разнообразных шлакощелочных бетонов на основе мета- и дисиликатов натрия.

Наиболее перспективной областью исследования для Крымского региона является шлакощелочной бетон на отходах камнепиления известняков Крымских карьеров на жидком стекле с Мс=1,5-1,7. Приблизительно 70 \% всего объема материала занимают отходы производств.

Вяжущее вещество - тонкомолотый доменный гранулированный шлак, отход металлургического производства, а также отход камнепиления бедых известняков и известняков-ракушечников Крымского региона исподьзуется как добавка при совместном помоле при изготовлении вяжущего. Отход камнепиления известняка-ракушечника в виде песка и щебня - как заполнители для бетона.

Свойства шлакощелочных вяжущих веществ, а именно набор прочности, скорость гидратации, твердение композиций зависят от химико-минералогического и фазового состава шлака, а также от природы щелочного компонента [4-6].

Научные и технологические основы управления структурообразованием и свойствами искусственных строительных материалов с наполнителями на основе клинкерного цемента, извести, гипсовых и органических вяжущих хорошо изучены, в частности, исследованы вопросы вдияния удельной поверхности и гранулометрического состава, поверхностной активности, химико-минералогического состава кдинкера и добавок на свойства вяжущих $[7,8]$.

Было изучено вдияние добавок на свойства вяжущих, свойства материалов на их основе в зависимости от вида и состава добавок, продолжительности и условий твердения, стабильность новообразований и долговечность портландцементного камня; известны положительные и отрицательные стороны использования раздичных добавок [9-13].

В настоящее время из геополимерных материалов наиболее исследованными по свойствам, составам, структуре и получившими применение являются шлакощелочные вяжущие и строительные композиты на их основе $[7,14]$. Но при этом недостаточно исследованы общие и частные закономерности влияния вещественного и гранулометрического состава, дисперсности и поверхностного потенциала отдельных видов шлаков, минеральных добавок и щелочных затворителей на структурообразование и свойства теста и камня шлакощелочного вяжущего.

Целью данной работы является оценка влияния вида карбонатных отходов на прочность, время твердения и структурообразование шлакощелочного бетона раздичных составов с разными условиями твердения на основе жидкого стекла с силикатным модулем 1,5-1,7 и отходов камнепиления известняков Крымских карьеров.

Для достижения поставленной цели решались следующие задачи:

1. Исследовалась прочность шлакощелочного бетона раздичных составов.

2. Проводилась оценка:

- влияния отходов камнепиления белого известняка и желтого известняка-ракушечника как добавки в шлак при совместном и раздельном помоле на прочность шлакощелочного бетона после тепловлажностной обработки (ТВО);

- вдияния отходов камнепиления белого известняка и желтого известняка-ракушечника как добавки в шлак при совместном и раздельном помоле на прочность шлакощелочного бетона при твердении в течение 28 суток в воздушных условиях;

- вдияния отходов камнепиления белого известняка и желтого известняка-ракушечника как добавки в шлак при совместном и раздельном помоле на прочность шлакощелочного бетона при твердении в течение 28 суток в водной среде;

- вдияния пылевидной фракции в мелком заполнителе на прочность шлакощелочного бетона, изготовленного по технодогии вибропрессования;

- влияния отходов камнепиления белого известняка и желтого известняка-ракушечника как добавки в шлак при совместном и раздельном помоле на сроки схватывания шлакощелочного вяжущего.

3. Проводияось исследование фазового состава:

- с помощью дифференциально-термического анализа;

- с помощью рентгенофазового анализа;

- с помощью микроструктурного анализа.

Характеристики используемых сырьевых материалов показаны ниже.

В качестве алюмосиликатной составдяющей ШЩВ в исследовании использовали размолотые до удельной поверхности 3100 - 3500 см²/г по ПСХ-4 основные доменные гранулированные шлаки Запорожского металлургического комбината, химический состав которых показан в табл. 1. Структура шлаков представлена в основном рентгеноаморфной стекловидной кальциево-алюмосиликатной массой, с небольшой примесью кристалдической фазы, представленной кальцитом $\mathrm{CaCO}$, бредигитом $2 \mathrm{CaO} \cdot \mathrm{SiO}_{2}$ и геленитом $\mathrm{CaO} \cdot \mathrm{Al}_{2} \mathrm{O}_{3} \cdot \mathrm{SiO}_{2}$ [17]. 
Химический состав металиургического шиака

\begin{tabular}{|c|c|c|c|c|c|c|c|}
\hline \multirow{2}{*}{ Минерал } & \multicolumn{7}{|c|}{ Содержание оксидов, \% } \\
\cline { 2 - 9 } & $\mathrm{SiO}_{2}$ & $\mathrm{Al}_{2} \mathrm{O}_{3}$ & $\mathrm{Fe}_{2} \mathrm{O}_{3}$ & $\mathrm{CaO}$ & $\mathrm{MgO}$ & $\mathrm{SO}_{3}$ & $\mathrm{P}_{2} \mathrm{O}_{5}$ \\
\hline Запорожский шиак & 41,66 & 3,52 & 1,015 & 47,78 & 3,03 & 0,34 & 0,008 \\
\hline
\end{tabular}

Рентгеноструктурный анализ доменного шлака Запорожского региона (рис. 1) свидетельствует, что шлак состоит в основном из гидросиликатов кальция типа CSH(B), характеризующихся межплоскостным расстоянием $\mathrm{d}=0,3014$ нм. Наблюдается уменьшение интенсивности пиков, которые не идентифицируются и относятся, по всей видимости, к двухкальциевому силикату $\beta-C_{2}$ S. На термограммах (рис. 2) у шиака отмечены пики в области температур 220-240 и 810-
$830{ }^{\circ} \mathrm{C}$, соответствующие ступенчатой дегидратации гидросиликатов кальция, и экзоэффект при $960{ }^{\circ} \mathrm{C}$ соответствует кристалдизации волластонита. На термограммах у известняков видно, что температуры максимума эндотермического эффекта составляют: у нуммулитового известняка $910{ }^{\circ} \mathrm{C}$, у известняка-ракушечника $960{ }^{\circ} \mathrm{C}$. Это свидетельствует о раздожении карбонатов кальция при данных температурах.

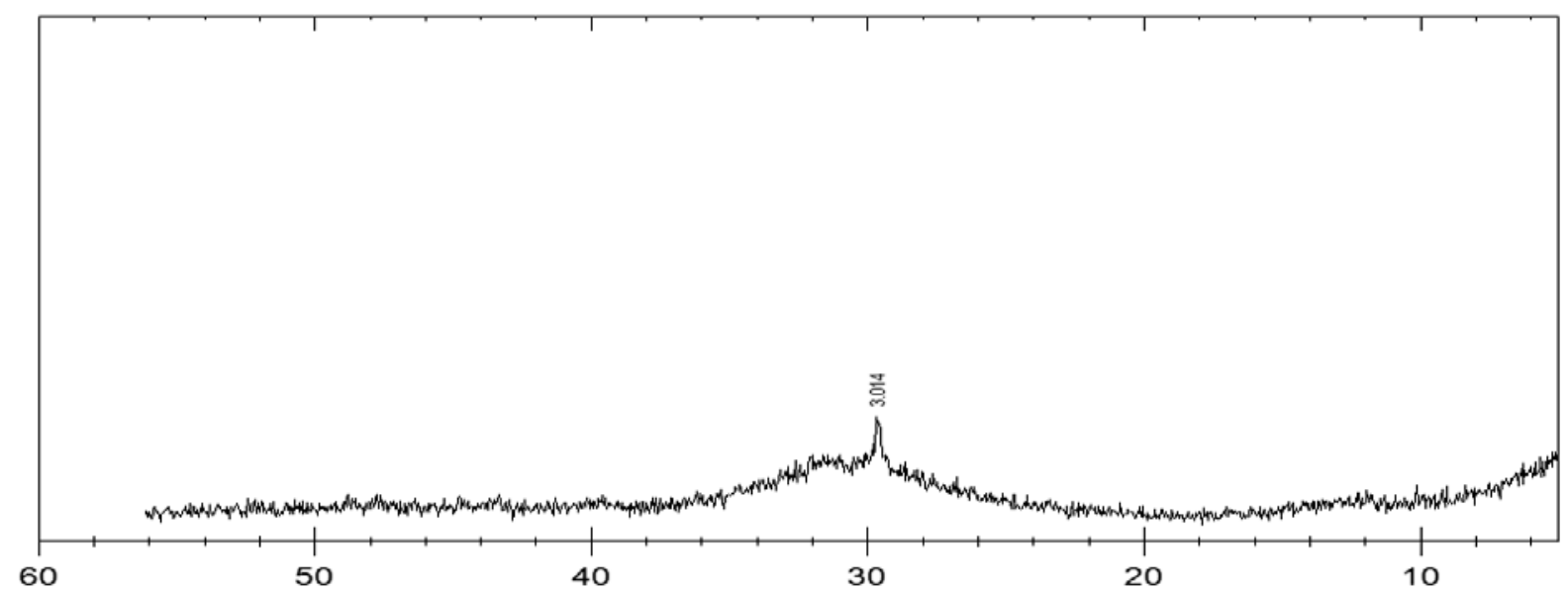

Рис. 1. Рентгенограмма доменного шлака Запорожского региона

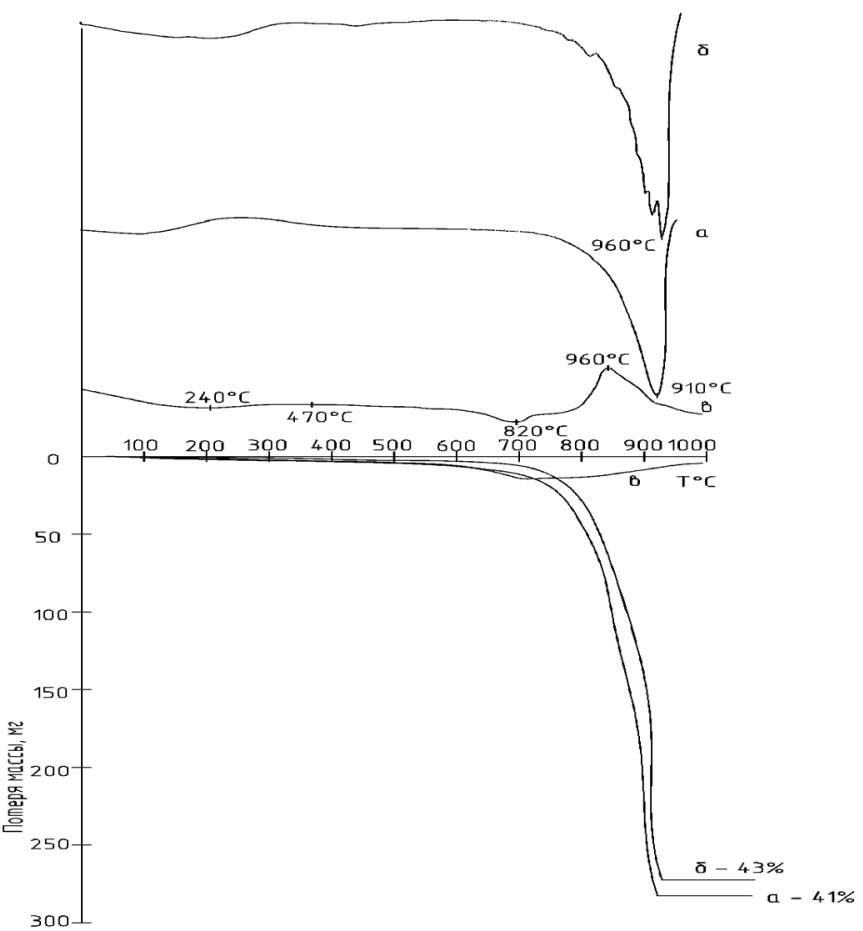

Рис 2. Дериватограмма исходных материалов для шлакощелочного бетона:

а - нуммулитовый известняк; б - известняк-ракушечник; в - шлак доменный гранулированный молотый 
Нуммулитовый белый известняк Бахчисарайского месторождения состоит из крупных нуммулитов, устриц, других молдюсков и детритусового материала. Это частично перекристалдизованная осадочная, плотная и достаточно прочная порода. По своему химическому составу (табл.2) нуммулитовый известняк характеризуется содержанием $\mathrm{CaCO}_{3}+\mathrm{MgCO}_{3}$ до $95,2 \%$.

Таблица 2

Химический состав нуммулитового известняка

\begin{tabular}{|c|c|c|c|c|c|c|c|}
\hline \multirow{2}{*}{ Материал } & \multicolumn{7}{|c|}{ Содержание оксидов, \% } \\
\cline { 2 - 9 } & $\mathrm{SiO}_{2}$ & $\mathrm{Al}_{2} \mathrm{O}_{3}$ & $\mathrm{Fe}_{2} \mathrm{O}_{3}$ & $\mathrm{CaO}$ & $\mathrm{MgO}$ & $\mathrm{SO}_{3}$ & п.п.п. \\
\hline Нуммудитовый известняк & 2,41 & 0,95 & 0,42 & 52,76 & 0,28 & 0,018 & 38,15 \\
\hline
\end{tabular}

Рентгеноструктурный анализ нуммулитового белого известняка Бахчисарайского месторождения (рис. 3) свидетельствует, что известняк состоит в основном из кальцита $\mathrm{d}=0,16 ; 0,187 ; 0,193 ; 0,228 ; 0,303 ; 0,384$ нм. Из примесей идентифицируется силиканит, характеризующийся расстоянием $\mathrm{d}=0,33$ нм, и гипс, характеризующийся межплоскостным расстоянием $\mathrm{d}=0,423$ нм.

Желтый известняк понтических отложений представдяет собой осадочную, неоднородную гор- ную породу, состоящую из раковин или их обломков раздичной величины, сцементированную известковым цементом. Структура породы детритусовая, текстура крупнопористая. Цвет светло-желтый [15].

Желтый известняк-ракушечник (Первомайский район, Крым) по химическому составу (табл. 3) характеризуется высоким содержанием карбонатов кальция и магния. Содержание $\mathrm{CaCO} 3+\mathrm{MgCO} 3$ по титру по $\mathrm{HCl}$ составляет от 85,2 до 98,4\%.

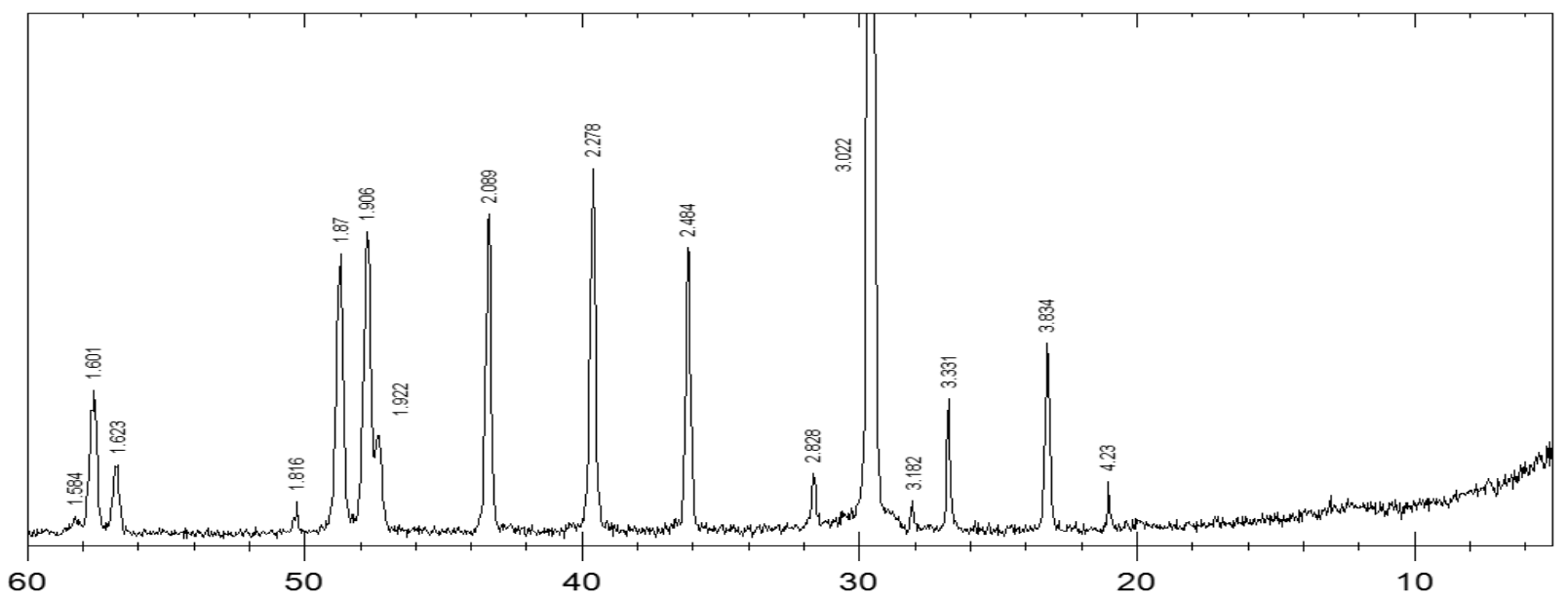

Рис. 3. Рентгенограмма нуммулитового белого известняка Бахчисарайского месторождения

Таблица 3

Химический состав известняка-ракушечника

\begin{tabular}{|c|c|c|c|c|c|c|c|}
\hline \multirow{2}{*}{ Материал } & \multicolumn{7}{|c|}{ Содержание оксидов, \% } \\
\cline { 2 - 9 } & $\mathrm{SiO}_{2}$ & $\mathrm{Al}_{2} \mathrm{O}_{3}$ & $\mathrm{Fe}_{2} \mathrm{O}_{3}$ & $\mathrm{CaO}$ & $\mathrm{MgO}$ & $\mathrm{SO}_{3}$ & п.п.п. \\
\hline Известняк-ракушечник & $0,01-3,56$ & $0,1-3,21$ & $0,1-1,14$ & $42,2-56,0$ & $0,19-1,74$ & $0,1-4,1$ & $33,6-44,0$ \\
\hline
\end{tabular}

Рентгеноструктурный анализ известняка-ракушечника Крымского карьера (рис. 4) свидетельствует, что известняк состоит в основном из кальцита $\mathrm{d}=0,16$; 0,187; 0,193; 0,228; 0,303; 0,384 нм. Из примесей идентифицируется силиканит, характеризующийся межплоскостным расстоянием $\mathrm{d}=0,33$ нм.

Желтый известняк-ракушечник и нуммулитовый белый известняк применяются в строительстве как стеновой материал, а также для производства извести.

Жидкое стекло получают из силикат-глыбы. Это твердая масса охлажденного расплава, полученного плавлением смеси кварцевого песка с содой или сульфатом натрия при 1300-1400 ${ }^{\circ} \mathrm{C}$. Химический состав силикат-глыбы приведен в табл. 4. 


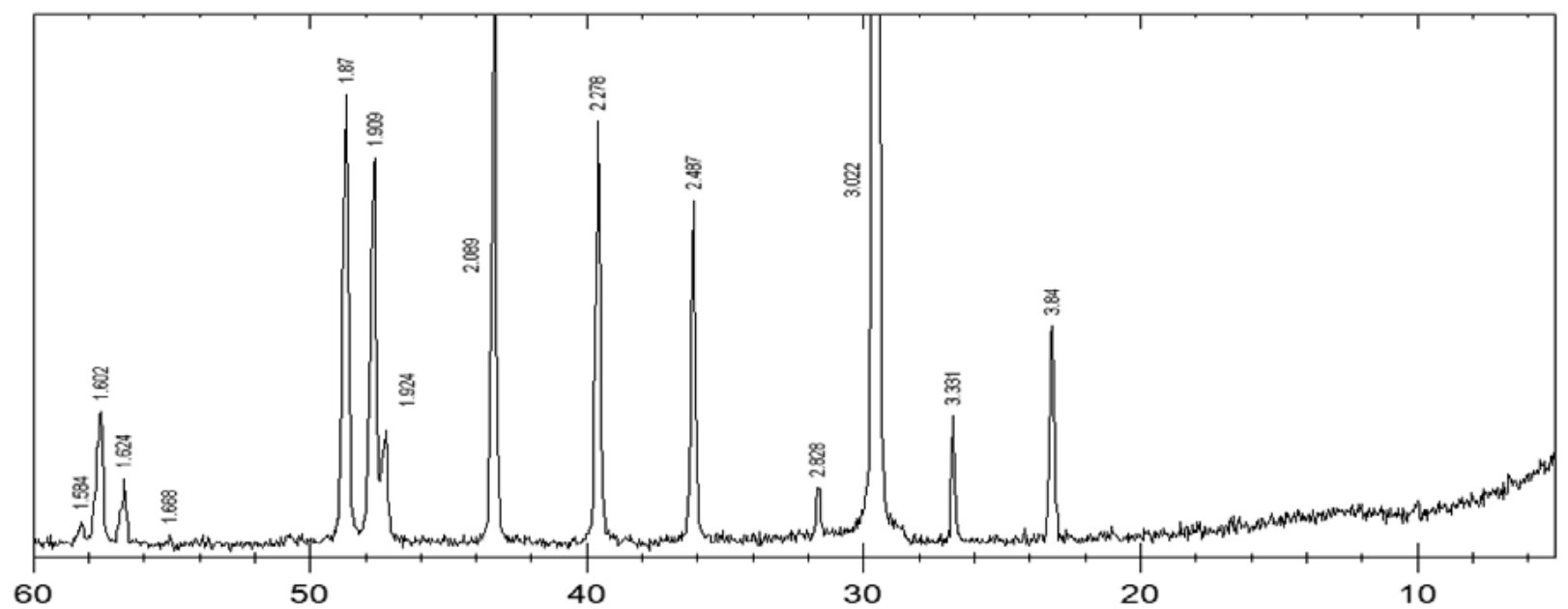

Рис. 4. Рентгенограмма известняка-ракушечника Крымского карьера

Таблица 4

Химический состав силикат-глыбы

\begin{tabular}{|c|c|c|c|c|c|}
\hline \multirow{2}{*}{$M_{c}$} & \multicolumn{5}{|c|}{ Содержание оксидов, \% } \\
\cline { 2 - 6 } & $\mathrm{Al}_{2} \mathrm{O}_{3}$ & $\mathrm{Al}_{2} \mathrm{O}_{3}++\mathrm{Fe}_{2} \mathrm{O}_{3}$ & $\mathrm{CaO}$ & $\begin{array}{c}\text { Серный } \\
\text { ангидрид }\end{array}$ & $\mathrm{Na}_{2} \mathrm{O}$ \\
\hline 2,8 & $70,8-73,4$ & 0,42 & 0,38 & 0,27 & $25,3-27,9$ \\
\hline
\end{tabular}

Примечание. Формула жидкого стекла - $\mathrm{Na}_{2} \mathrm{O}, \mathrm{nSiO} 2$, где n - силикатный модуль жидкого стекла.

В качестве основного состава бетона выбран оптимальный состав по результатам проведения оценочного ряда матриц, в которых исследовались зависимости прочности на сжатие, после тепловлажностной обработки (ТВО) по режиму $(2+3,5+4,5)$, при температуре изотермического прогрева $\mathrm{t}=70{ }^{\circ} \mathrm{C}$, плотности бетона и однородности поверхности при варьировании таких факторов, как количество щебня и шлака, процентное содержание добавки в шлаке. Основной состав в натуральных величинах имеет вид: щебень из известняка-ракушечника Щ = $850 \mathrm{kг} / \mathrm{M}^{3}$; песок из известняка-ракушечника $П=771 \mathrm{\kappa г} / \mathrm{M}^{3}$; шлак

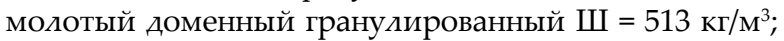
раствор жидкого стекла Жст = 231 л; плотность жидкого стекла $\rho_{\text {ж.ст. }}=1,15$ г $/ \mathrm{cm}^{3}$.

В исследованиях оценивалось влияние отходов камнепиления белого известняка и желтого известняка-ракушечника как добавки в шлак при совместном и раздельном помоле на прочность бетона после тепловлажностной обработки и в возрасте 28 суток твердения в воздушно-влажных условиях и в водной среде, а также вдияние пылевидной фракции в мелком заполнителе на прочностные показатели бетона.

По каждому составу было изготовлено по 5 образцов цилиндров диаметром 7 см для определения прочности на сжатие после ТВО и в 28-суточном возрасте твердения в воздушно-влажных условиях и в воде. Также по всем образцам определялась плотность бетона.

Данные по плотности и прочности образцов цидиндров диаметром 7 см после ТВО и в 28-суточном возрасте твердения в воздушно-влажных условиях и в воде, а также показатели факторов вдияния представлены в табл. 5.

Перед исследованиями вдияния карбонатных отходов Крымских карьеров на сроки схватывания шлакощелочного вяжущего было установлено следующее:

- сроки схватывания шлакощелочного вяжущего вещества на жидком натриевом стекле с силикатным модулем $\mathrm{M}_{c}=1,5-1,7$ зависят от растворошиакового отношения (Р/Ш), плотности жидкого стекла и тонкости помола шлака;

- прочность шлакощелочного цементного камня зависит от тонкости помола шлака, возраста шлака после помола, плотности жидкого стекла и Р/Ш;

- оптимальная область удельной поверхности помола шлака находится в пределах 3000$3300 \mathrm{~cm}^{2} / \Gamma$; 
Сводная таблица данных плотности и прочности образцов цилиндров

\begin{tabular}{|c|c|c|c|c|c|c|c|c|c|c|}
\hline \multirow[b]{2}{*}{$\begin{array}{c}\text { № } \\
\text { состава }\end{array}$} & \multicolumn{3}{|c|}{ Факторы влияния } & \multirow{2}{*}{ 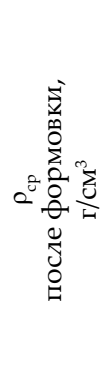 } & \multirow[b]{2}{*}{ 号 } & \multirow{2}{*}{ 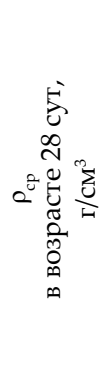 } & \multirow{2}{*}{ 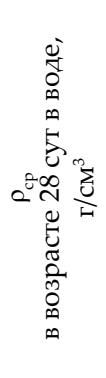 } & \multirow{2}{*}{ 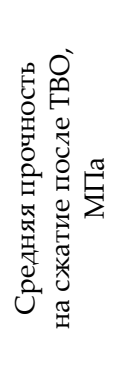 } & \multirow{2}{*}{ 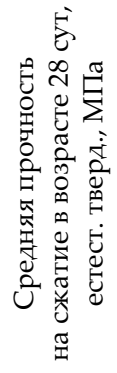 } & \multirow{2}{*}{ 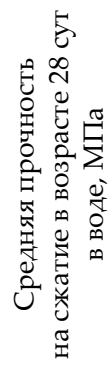 } \\
\hline & 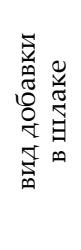 & 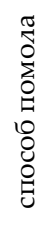 & 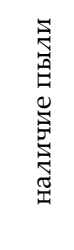 & & & & & & & \\
\hline 1 & - & - & Есть & 2,19 & 2,16 & 2,23 & 2,24 & 29,6 & 29,8 & 31,3 \\
\hline 2 & - & - & Нет & 2,18 & 2,21 & 2,16 & 2,16 & 33,3 & 28,9 & 24,4 \\
\hline 3 & БИ & $\mathrm{C}$ & Есть & 2,24 & 2,19 & 2,22 & 2,25 & 20,0 & 25,4 & 24,9 \\
\hline 4 & БИ & $\mathrm{C}$ & Нет & 2,21 & 2,19 & 2,19 & 2,22 & 20,1 & 23,5 & 19,0 \\
\hline 5 & ЖИ & $\mathrm{C}$ & Есть & 2,24 & 2,24 & 2,21 & 2,25 & 22,3 & 23,8 & 23,6 \\
\hline 6 & ЖИ & $\mathrm{C}$ & Нет & 2,23 & 2,23 & 2,19 & 2,24 & 23,6 & 18,9 & 25,8 \\
\hline 7 & БИ & $\mathrm{P}$ & Есть & 2,18 & 2,20 & 2,20 & 2,15 & 25,6 & 25,7 & 17,2 \\
\hline 8 & БИ & $\mathrm{P}$ & Нет & 2,16 & 2,12 & 2,17 & 2,14 & 23,0 & 26,2 & 21,5 \\
\hline 9 & ЖИ & $\mathrm{P}$ & Есть & 2,14 & 2,14 & 2,17 & 2,10 & 22,8 & 22,3 & 13,6 \\
\hline 10 & ЖИ & $\mathrm{P}$ & Нет & 2,16 & 2,20 & 2,14 & 2,12 & 25,5 & 26,3 & 17,1 \\
\hline
\end{tabular}

Примечание. БИ - белый известняк в количестве 30 \% от массы вяжущего; ЖИ - желтый известняк-ракушечник в количестве 30 \% от массы вяжущего; С - совместный помол шиака с добавкой известняка; Р - раздельный помод шлака с добавкой известняка.

- $\quad$ оптимальные границы плотности жидкого стекла с силикатным модулем $\mathrm{M}_{\mathrm{c}}=1,5-1,7$ для контролирования сроков схватывания и прочностных характеристик находятся в пределах 1,14-1,18 г/см².

Для исследования были использованы карбонатные отходы камнепиления нуммулитового известняка, известняка-ракушечника и цеолита как добавки при совместном и раздельном помоле с доменными гранулированными шлаками.

Было исследовано влияние совместного и раздельного помола доменного гранулированного шиака, карбонатных отходов камнепиления нуммулитового известняка и известняка-ракушечника на сроки схватывания и прочность шлакощелочного вяжущего. Определение сроков схватывания ШЩВ проводидось по стандартной методике.

С целью идентификации новообразований, определения продуктов взаимодействия компонентов вяжущих и изменения их во времени проводился комплексный физико-химический анализ: микроскопический, рентгеноструктурный и дериватографический.

Микроструктура ШЩБ исследована с использованием электронного микроскопа PEM-106, SELMI. Растровый электронный микроскоп РЕМ-106 предназначен для исследования рельефа поверхности проводящих и диэлектрических объектов в режиме высокого и низкого вакуума. Разрешающая способность микроскопа в режиме высокого вакуума - 4 нм, в режиме низкого вакуума - 6 нм.
Рентгенофазовый анализ известняков, шлака и образцов из шлакощелочного бетона выполнен на рентгеновском аппарате ДРОН-5 с режимом съемки: издучение $\mathrm{Fe}$, напряжение $\mathrm{V}=30 \mathrm{kB}$, сила тока $\mathrm{A}=$ 20 мА, диапазон скорости счетчика 200 имп/с, скорость вращения счетчика 2 град/мин.

Комплексный термический анализ выполнен на дериватографе Q -1500 D с одновременной съемкой четырех кривых: интегральной кривой нагревания (T), дифференциальной кривой нагревания (ДТА), кривой изменения массы (ТГ), дифференциальной термогравиметрической кривой (ДТГ), по которым определяли тепловые эффекты, сопровождающие фазовые превращения и химические реакции. Режимы анализа следующие: диапазон 0 - 1273 K; чувствительность Т 1000, ТГ - 500, ДТГ - 1/15, ДТА - 1/15; скорость подъема температуры $10{ }^{\circ} \mathrm{C} /$ мин; время нагрева -6000 с.

Объектом проводимых исследований явидись образцы цилиндры диаметром 7 см.

Образцы 5-7 с компонентом желтого известняка и белого известняка показаны на рис. 5 - 7. Несмотря на некоторые отличия по прочностным характеристикам исследуемых составов (см. табл. 5), процессы структурообразования в этих системах в целом идентичны и определяются в основном минералогическим составом карбонатов.

Первый эндотермический эффект в диапазоне температур 190-200 ${ }^{\circ} \mathrm{C}$ соответствует удалению свободной цеолитной воды, введенной при формовании образцов. Затем наблюдается экзотермический эф- 


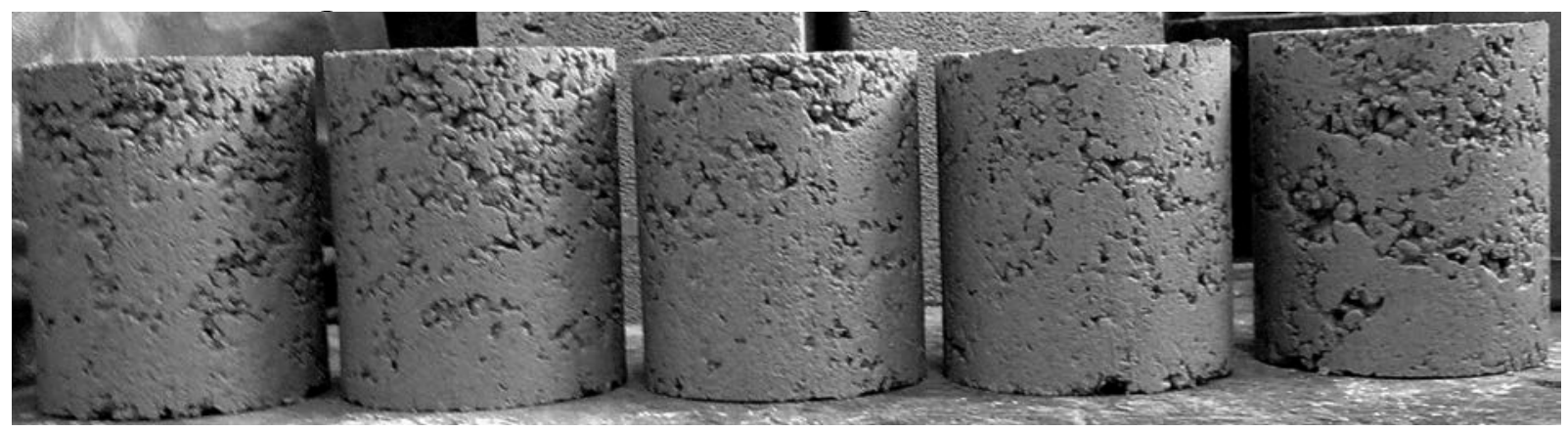

Рис. 5. Образцы после формования. Состав 5

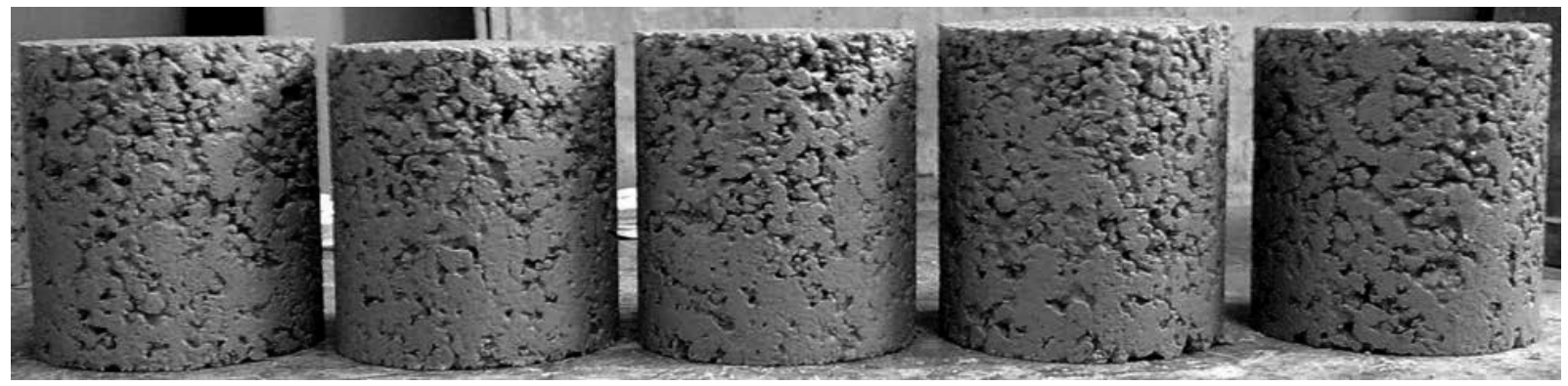

Рис. 6. Образцы после формования. Состав 6

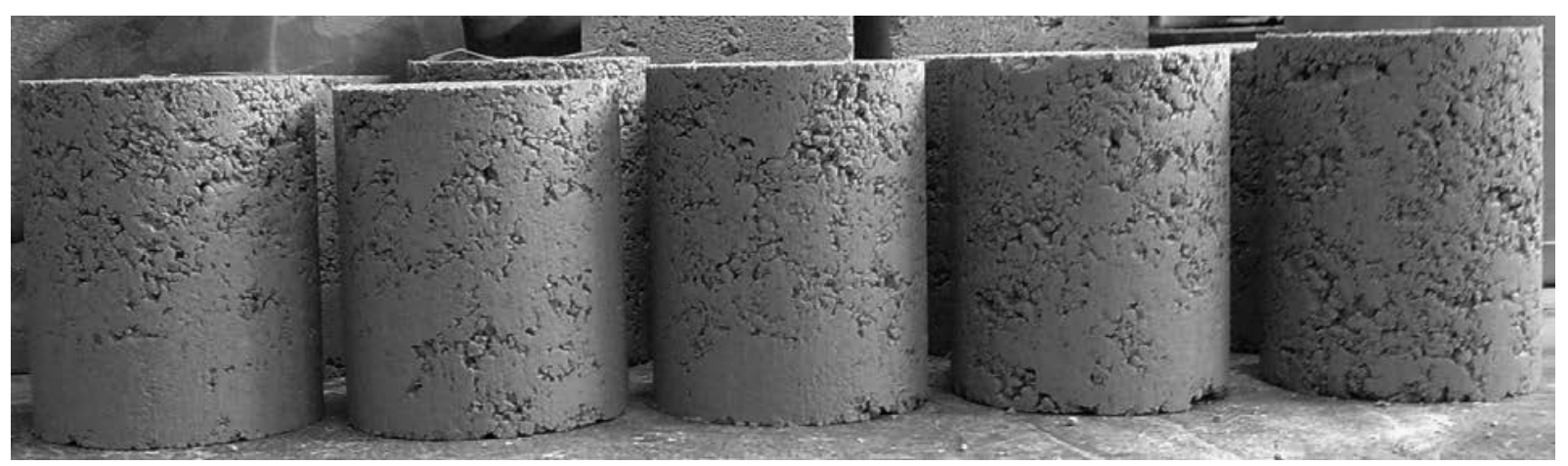

Рис. 7. Образцы после формования. Состав 7

фект в диапазоне температур 320-400 ㄷ, свидетельствующий о цеодитных свойствах воды, содержащейся в полученных соединениях, относящихся к кальциевым гидросиликатам. Эндотермический эффект при 910-960 으 объясняется возникновением в составе новообразований новых цеодитоподобных веществ за счет взаимодействия сидиката натрия как со свободной щелочью, так и с карбонатами кальция, которые в свою очередь при данной температуре диссоциируют с выделением $\mathrm{CO}_{2}$. Потеря массы при этом находится в пределах 36-37 \%.

Рентгенофазовый анализ исследуемых образцов представлен на рис. 9. Главным образом структура данного вида бетона состоит из кальцита (динии $\mathrm{d}=$ 0,$16 ; 0,187 ; 0,193 ; 0,228 ; 0,303 ; 0,384$ нм), тоберморита (линии $\mathrm{d}=0,158 ; 0,167 ; 0,191 ; 0,283 ; 0,333$ нм).
Исследование микроструктуры образца из шлакощелочного бетона, с применением карбонатных отходов, как наполнитель в шлак и как заполнитель представлено на рис.10.

Образцы 5,7 твердели в водной среде, а образец 6 - в воздушной. Поэтому для образцов 5,7 отсутствует правильное и четкое ограничение кристаллов, что способствует наиболее плотной их упаковке и обеспечивает высокую прочность камня. Видны крупные призматические, пластинчатые и игольчатые кристалды, взаимодействующие друг с другом.

Поверхность представляет собой монолит с редкими включениями пор, в которых закристалдизовались щелочные гидроалюмосиликаты (рис. 10). Это приводит к кристалдизации продуктов твердения, которые можно идентифицировать по рентгенограммам как $\mathrm{C}-\mathrm{S}-\mathrm{H}$. 


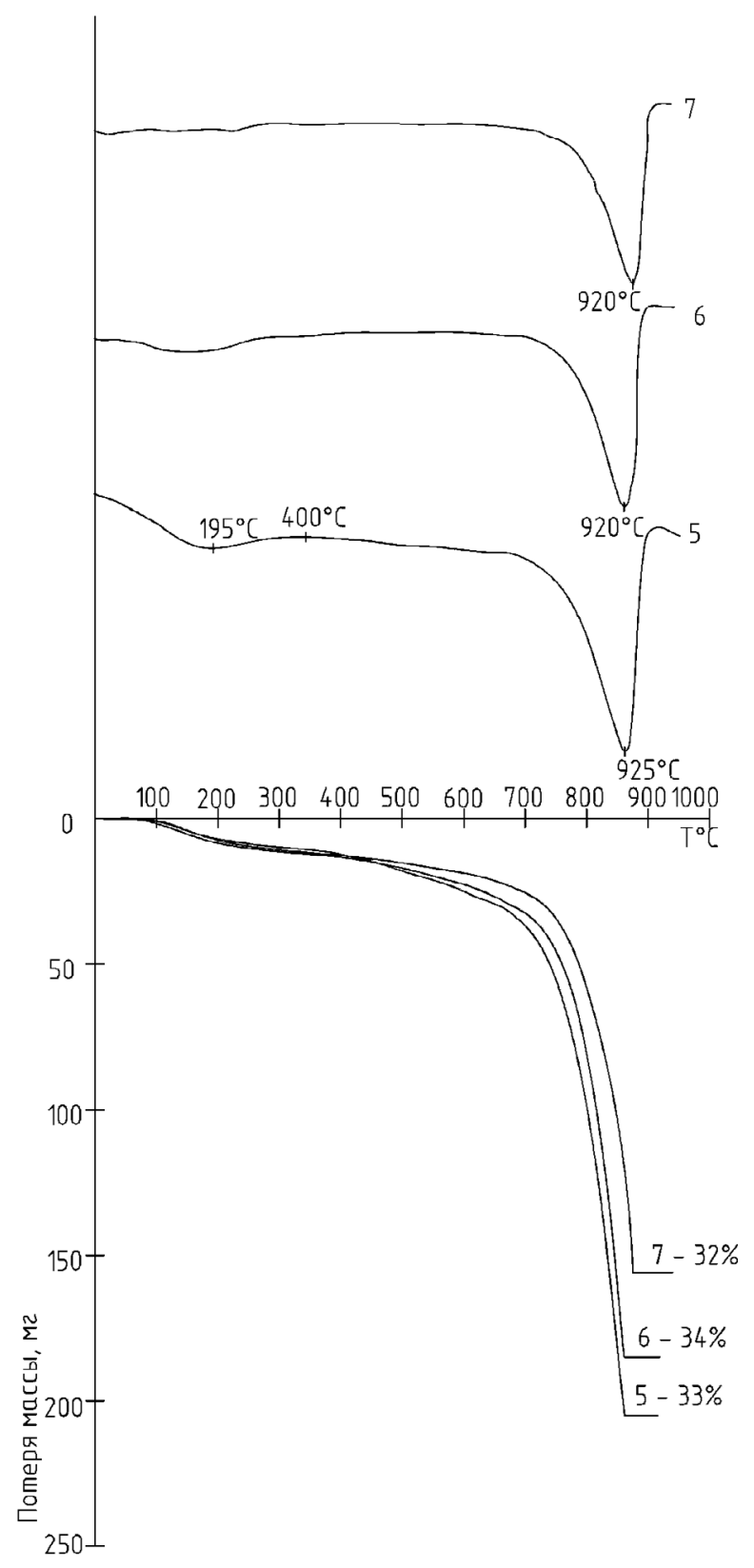

Рис.8. Дериватограмма образцов 5 - 7 


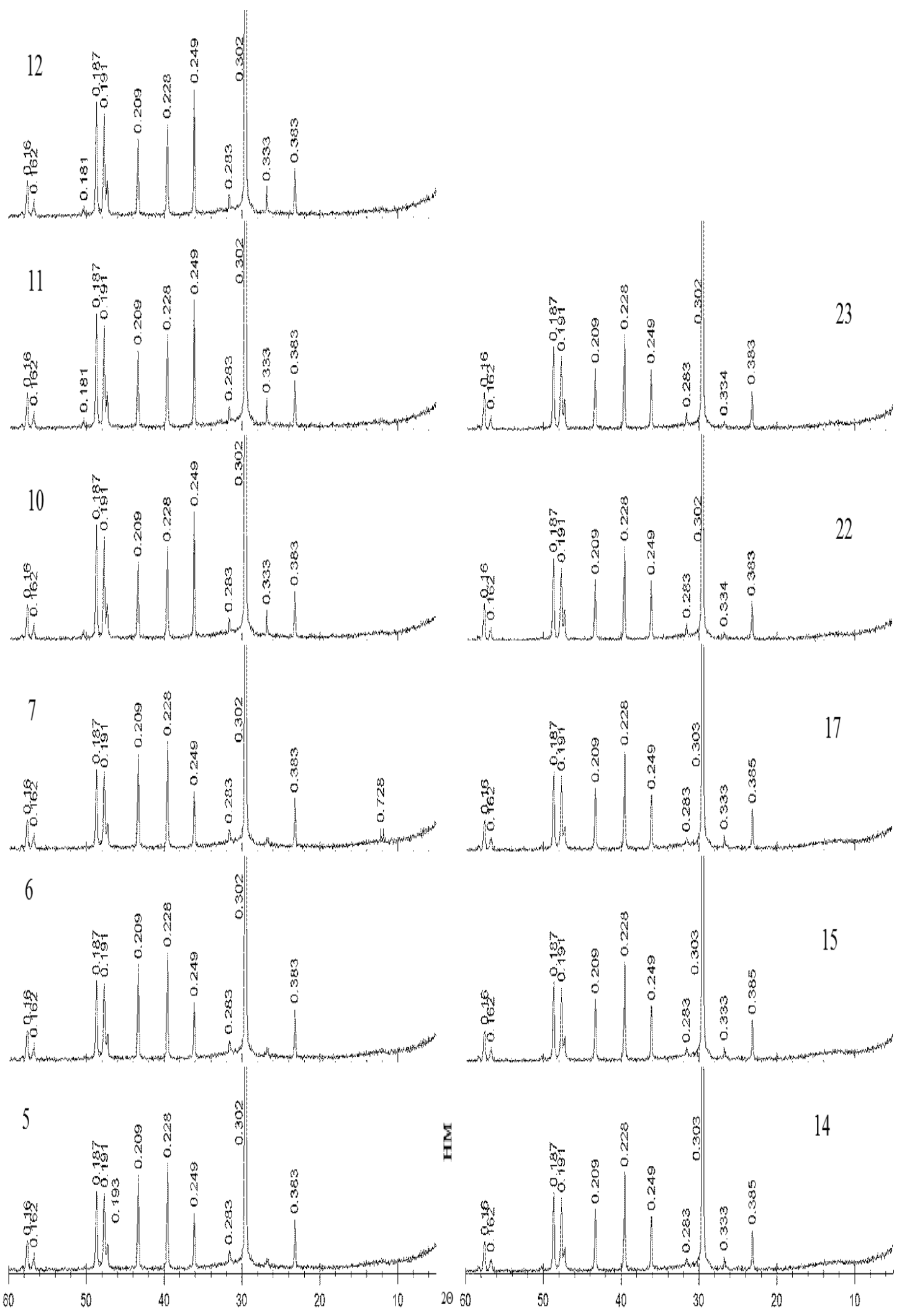

Рис. 9. Рентгенограмма образцов 5 - 7 
a

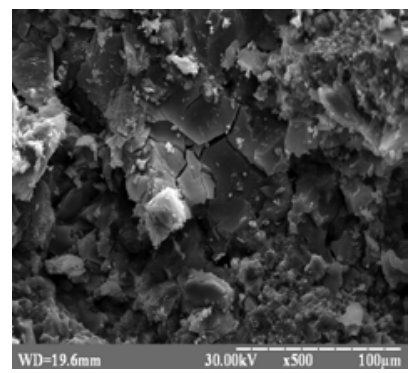

$\mathbf{r}$

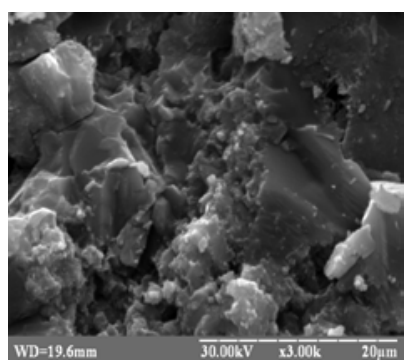

б

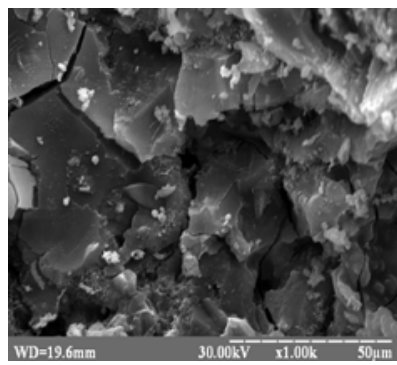

A

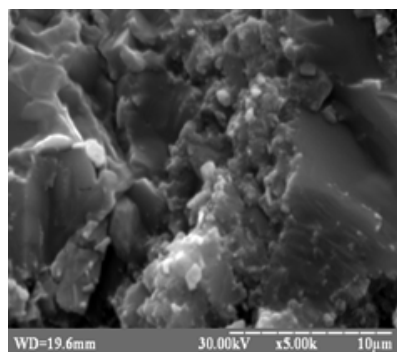

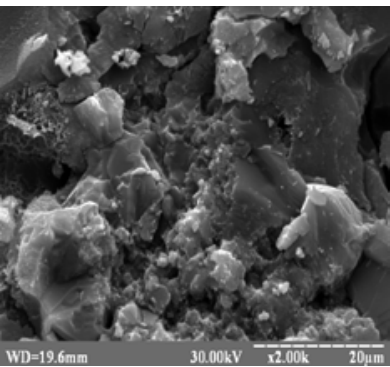

e

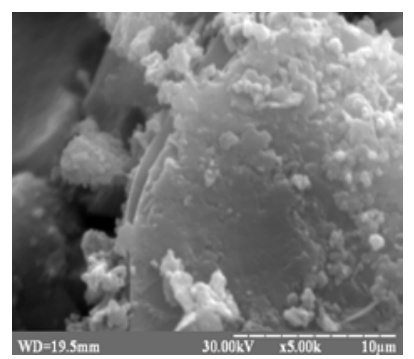

Рис. 10. Микроструктура образцов 5 - 7 с раздичным увеличением: a - х500; б-x1000; в-х2000; г - х3000; д-х5000; e-x5000

Результаты электронно-микроскопических исследований подтверждают данные рентгенофазового и дифференциально-термического анализов.

Также на рис. 10 у опытных образцов 5 - 7 наблюдаются крупные кристалды кальцита размером $1-4$ мкм, связанные между собой массой вещества с многочисленными центрами кристаллизации субмикроскопической величины.

\section{Выводы:}

- максимальное значение предела прочности при сжатии шлакощелочного бетона с исподьзованием отходов камнепиления известняков Крымских карьеров составило 33 МПа;

- наличие пылевидной фракции в мелком заполнителе положительно влияет на прочность бетона у образцов, твердеющих 28 суток в воздушно-влажных условиях;

- изменение прочностных характеристик образцов с введением белого нуммулитового или желтого известняка-ракушечника в виде добавки составдяет 20 - 25 МПа;

- условие раздельного помола существенно понижает прочность образцов в возрасте 28 суток в водной среде;

- сроки схватывания шлакощелочного вяжущего вещества на жидком натриевом стекле с силикатным модулем $\mathrm{M}_{\mathrm{c}}=1,5-1,7$ зависят от растворошлакового отношения, плотности жидкого стекла и тонкости помола шлака;
- оптимальная область удельной поверхности помола шлака, для контроля сроков схватывания и прочностных характеристик, находится в пределах 3000-3300 см²/г;

- оптимальные границы плотности жидкого стекла, для контроля сроков схватывания и прочностных характеристик, находятся в пределах 1,14-1,18 г/ см;

- шлак с добавкой белого нуммулитового известняка и известняка-ракушечника уведичивает время начала и окончания схватывания ШЩВ;

- проведенные исследования показали, что карбонатный наполнитель с его примесями вступает во взаимодействие не только со свободной щелочью, образующейся в процессе гидратации вяжущего, но и непосредственно с карбонатом натрия;

- возникающие при этом новообразования представдяют собой кристаллические цеолитоподобные вещества щелочного алюмосиликатного состава, которые наряду с низкоосновными гидросиликатами кальция и кальцитом могут служить структурообразующими элементами в шлакощедочных бетонах на отходах камнепиления известняка-ракушечника с содержанием глинистых и пылевидных частиц до 15 \% и тем самым оказывают положительное влияние на их свойства. 


\section{БИБЯИОГРАФИЧЕСКИЙ СПИСОК}

1. Чумаченко Н.Г. Ресурсосберегающий подход к сырьевой базе стройиндустрии // Градостроительство и архитектура. 2011. № 1. С. 112-116. DOI: 10.17673/ Vestnik.2011.01.22

2. Вавилова Т.Я. Ретроспективный обзор документов ООН по проблемам устойчивого развития среды жизнедеятельности // Градостроительство и архитектуpa. 2011. № 1. C. 24-28. DOI: 10.17673/Vestnik.2011.01.5

3. Арбузова Т.Б., Чумаченко Н.Г. Проблемы стройиндустрии и возможные варианты решений // Известия вузов. Строительство. 1995. № 3. С. 37-40.

4. Производство бетонов и конструкций на основе ШЩВ / под ред. В. Д. Глуховского. К.: Будівельник, 1988. $144 \mathrm{c}$

5. Глуховский В.Д. Грунтосидикаты. Киев: Госстройиздат, 1959. 128 с.

6. Кривенко П.В., Пушкарева Е.К. Долговечность шлакощелочного бетона. К.: Будівельник, 1993. 224 с.

7. Кривенко П.В. Закономерности формирования структуры и свойств цементного камня на шлакощелочных вяжущих // Цемент. 1985. №3. С.15-16.

8. Аюбомирский Н.В. Известковые материалы карбонизационного твердения. Симферополь: Доля, 2013. 320 c.

9. Рахимова Н.Р. Шиакощелочные вяжущие и бетоны с силикатными и алюмосиликатными минеральными добавками: автореф. дис. ... докт. техн. наук. Казань, 2010. 42 с.

Об авторах:

\section{СВИЩ Игорь Станиславович}

кандидат технических наук, доцент кафедры строительного инжиниринга и материаловедения

Крымский федеральный университет им. В.И. Вернадского Академия строительства и архитектуры 295007, Россия, Республика Крым, г. Симферополь, ул. Киевская, 181, каб. 210,

тел. (978) 752-79-30

E-mail: igorswishch@gmail.com

\section{НОСАТОВА Елена Витальевна}

соискатель кафедры строительного инжиниринга и материаловедения

Крымский федеральный университет им. В.И. Вернадского Академия строительства и архитектуры 295007, Россия, Республика Крым, г. Симферополь, ул. Киевская, 181, каб. 210,

тел. (978) 786-48-11

E-mail: nosatovae@mail.ru
10. Носатова Е.В. Исследование влияния карбонатных отходов и цеолитов на физико-механические свойства мелкозернистых ШЩБ на основе жидкого стекла с силикатным модулем Мс =1,5-1,7 // Motrol. Motoryzacja i energetyka rolnictwa. Lublin, 2013. Vol. 17. P. 205 - 211.

11. Свищ И.С., Носатова Е.В. Исследование вдияния карбонатных отходов и цеолитов на сроки схватывания, прочность и качество ШЩБ на основе жидкого стекла с силикатным модулем Мс $=1,5-1,7$ // Строительство и техногенная безопасность: сб. науч. трудов. Вып.47. Симферополь: НАПКС, 2013.

12. Свищ И., Носатова Е., Носатов В. Материалосберегающие факторы в технологии производства стеновых изделий из шлакощелочных бетонов на отходах камнепиления известняков ракушечников и жидких стеклах с силикатным модулем Мс = 1,5...1,7 после тепловлажностной обработки // Motrol. Motoryzacja i energetyka rolnictwa. Lublin, 2013. Vol. 17. P. 211-217.

13. Свищ И.С., Носатова Е.В. Влияние вида карбонатных отходов на прочность шлакощелочного бетона на основе жидкого стекла с силикатным модулем 1,5 -1,7 после ТВО // Строительство и техногенная безопасность: сб. науч. трудов. Вып.47. Симферополь: НАПКС, 2013.

14. Кононов В.П., Пахомов В.А., Трощеновский А.П. Экспериментадьные исследования прочности и модуля упругости шлакощелочного бетона на высокомодульном жидком стекле // Сб. научных трудов Пермского политехнического института. Реферативный журнал. Серия 8. М.: ВНИИС, 1982. № 9-10.

15. Аушпаева П.П. Строительные материалы Крыма: справочник. Симферополь - Таврия, 1987. 156 с.

\section{SVISHCH Igor S.}

$\mathrm{PhD}$ in Engineering Science, Associate Professor of the Construction Engineering Materials and Technology Chair Crimean Federal University named after V.I. Vernadskij Academy of Construction and Architecture 295007, Russia, Crimea, Simferopol, Kievskaya str., 181, tel. (978) 752-79-30

E-mail: igorswishch@gmail.com

\section{NOSATOVA Elena V.}

Candidate of $\mathrm{PhD}$ Degree of the Construction Engineering Materials and Technology Chair

Crimean Federal University named after V.I. Vernadskij

Academy of Construction and Architecture

295007, Russia, Crimea, Simferopol, Kievskaya str., 181, tel. (978) (978) 786-48-11

E-mail: nosatovae@mail.ru

Для цитирования: Свищ И.С., Носатова Е.В. Влияние вида карбонатных отходов Крымских карьеров на прочность, время твердения и структурообразование шлакощелочного бетона на основе жидкого стекла с силикатным модулем 1,5-1,7 // Градостроительство и архитектура. 2017. Т.7, №2. С. 53-63. DOI: 10.17673/Vestnik.2017.02.9.

For citation: Svishch I.S., Nosatova E.V. Influence of type of Crimean quarries carbonate waste on durability, curing time and structure formation of slag-lime concrete on the basis of soluble glass with silicate module 1,5-1,7 // Urban Construction and Architecture. 2017. V.7, 2. Pp. 53-63. DOI: 10.17673/Vestnik.2017.02.9. 